\title{
RICE SEEDLING ESTABLISHMENT AS INFLUENCED BY CULTIVARS AND SEED PRIMING WITH POTASSIUM NITRATE
}

\author{
Talha Javed ${ }^{1, * \dagger}$, Muhammad Moaaz Ali ${ }^{2, *}$, Rubab Shabbir ${ }^{1}$, Shaista Gull ${ }^{3}$, Ahmad Ali ${ }^{1}$, Ehsan
} Khalid $^{6}$, Anam Noreen Abbas ${ }^{4}$, Mubashir Tariq ${ }^{4}$ and Muqmirah ${ }^{5}$

${ }^{1}$ College of Agriculture, Fujian Agriculture and Forestry University, Fuzhou, Fujian 350002, China;

${ }^{2}$ College of Horticulture, Fujian Agriculture and Forestry University, Fuzhou, Fujian 350002, China;

${ }^{3}$ Department of Horticulture, Bahauddin Zakariya University, Multan 66000, Pakistan;

${ }^{4}$ College of Plant Protection, Fujian Agriculture and Forestry University, Fuzhou, Fujian 350002, China;

${ }^{5}$ Hixia Institute of Science and Technology, Fujian Agriculture and Forestry University, Fuzhou, Fujian 350002, China

${ }^{6}$ National Agricultural Research Council, Pakistan

*Equally Contributed Authors

${ }^{\dagger}$ Corresponding author: talhajaved54321@ gmail.com; Tel: +86-18396515902

Article Received 03-08-2020, Revised 20-08-2020, Accepted 24-08-2020

\section{Abstract}

Poor crop establishment is one of the major constraints to obtain the higher potential of rice, particularly in areas prone to environmental stresses. Therefore, present study was conducted to evaluate the effects of potassium nitrate on germination dynamics, seedling growth and associated physiological and biochemical events of two rice cultivars. For this purpose, various seed priming treatments were tested in lab and greenhouse. The percent concentrations of potassium nitrate were $0.25,0.50,0.75,1.0$ and 1.25 in both lab evaluation and greenhouse experiment. Non-primed seeds were maintained as a control for comparison. The results depicted that soaking rice seeds at higher concentrations of $\mathrm{KNO}_{3}$ could delay emergence time and final emergence (\%) in both cultivars under lab and greenhouse conditions. Seed priming with $0.75 \% \mathrm{KNO}_{3}$ significantly increased the stand establishment and seedling vigor attributes of both cultivars compared with other concentrations and naked rice seeds both in lab evaluation and greenhouse screening. Similarly, highest values for photosynthesis rate, evaporation rate and $\mathrm{CO}_{2}$ index were observed in experimental units receiving primed seeds with $0.75 \% \mathrm{KNO}_{3}$ under greenhouse screening. Interestingly, no variance was observed among both rice cultivars. Overall, higher seed emergence, seedling vigor and associated biochemical attributes due to seed priming with $0.75 \% \mathrm{KNO}_{3}$ was associated with decrease in alcohol dehydrogenase (ADH) and pyruvate decarboxylase (PDH) activities in lab and greenhouse screening.

Keywords: Seed priming, potassium nitrate, seed quality, stand establishment, vigor

\section{Introduction}

Rice is an important cereal crop that serve as staple food for almost half of the world population (Chun et al. 2020; Zafar et al. 2020). Its germination is affected under various environmental stresses which causes poor yield (Zafar et al. 2015; Zafar et al. 2018). Poor germination is the problem often faced by different farmers of rice, especially when the seed is broadcasted in dry condition. Under unfavorable and harsh environmental condition, seed priming method is the best technique which help the seed to germinate easily. It enhances the germination chances and boost up the process (Ahmed et al., 2019), and is a cheaper solution to overcome poor stand establishment (Farooq et al., 2009; Harris et al., 1999). It has been reported that the seed priming is very helpful in improving germination rate of many crops i.e., rice, wheat, maize and canola (Basra et al., 2005). The germination percentage and dry weight of seedlings of safflower was increased by seed priming (Razaji et al., 2012). It has been reported that the inferior quality of wheat could also grow well after seed priming (Hussian et al., 2013). Increase in germination rate, uniformity in process, improved plant growth and yield, and better physiological performance are included in the beneficial aspects of seed priming (Farooq et al., 2007; Ruan et al., 2002). The seed priming principle 
is based on the behavior of seed towards water absorption; water is very important factor for seed germination and growth. The water intake of seed is divided into three phases. First phase includes the intake of water by seed and activation of enzymes. In $2^{\text {nd }}$ phase, after activation of enzymes, several processes such as food deprivation, cell membrane restructuring and biosynthesis of starch occur to support seedling and root growth. In final phase, the growth of root and shoot organs i.e., radicle and plumule takes place (Bewley et al., 2013). There are three categories of seed priming techniques; (1) hydro-priming priming with simple water, (2) solid-matrix priming - priming with solid organic material and (3) osmopriming - priming with priming solutions e.g., potassium nitrate $\left(\mathrm{KNO}_{3}\right)$, potassium chloride $(\mathrm{KCl})$ and polyethylene glycol (PEG) (McKersie, 2002; Mohammadi, 2009). PEG and $\mathrm{KNO}_{3}$ are commonly used in priming studies, but PEG is more expensive than $\mathrm{KNO}_{3}$. In a previous study, it was demonstrated that the osmopriming of seed of soybean with $\mathrm{KNO}_{3}$ at the concentration of 6 $\mathrm{g} / \mathrm{L}$ increased the germination percentage and dry weight of seedling (Ahmadvand et al., 2012). Similarly, seed priming with $1.0 \%$ $\mathrm{KNO}_{3}$ for $24 \mathrm{~h}$ at $20^{\circ} \mathrm{C}$ enhance the germination rate and improved the physiological quality of soybean (Mohammadi, 2009). Moreover, it has also been reported that the seed priming could improve the protein synthesis during early growth of embryo (Xu et al., 2009). Here in this study, the aim was to evaluate the effect of seed priming with different concentrations of $\mathrm{KNO}_{3}(0.25 \%, 0.50 \%, 0.75 \%, 1.0 \%$ and $1.25 \%(\mathrm{w} / \mathrm{v}) \mathrm{KNO}_{3}$ for 1 day at $25^{\circ} \mathrm{C}$ ) on the stand establishment, seedling vigor, physiological and biochemical attributes of two rice cultivars.

\section{Materials and Methods}

Seed Source: Seed of Indica rice (Oryza sativa L.) cultivars viz., Basmati-515 and Basmati-385 were obtained from Rice Research Institute, Kala Shah Kaku, Punjab, Pakistan. The initial germination and seed moisture content prior to seed treatment was
$>80 \%$ and $12 \%$ respectively on dry weight basis.

Seed Priming Treatments: Rice seeds were primed with $0.25 \%, 0.50 \%, 0.75 \%, 1.0 \%$ and $1.25 \%(\mathrm{w} / \mathrm{v}) \mathrm{KNO}_{3}$ for $24 \mathrm{~h}$ at $25^{\circ} \mathrm{C}$. Preweighed seeds $(5 \mathrm{~g})$ were placed on two blotter papers in 9-cm diameter petri dishes saturated with appropriate concentration of osmotic solutions followed by covering of dishes with aluminum foil. Non-primed rice seeds were maintained as control for comparison. Seeds were stored at $-4^{\circ} \mathrm{C}$ in paper bags, prior to experimentation.

Experimental Site and Conditions: Lab experiment was conducted in the growth chamber of Seed Preservation Lab, National Agricultural Research Centre, Islamabad, Pakistan during September 2019 to October 2019. While, greenhouse experiment was conducted at the research station of National Agricultural Research Centre, Islamabad, Pakistan during September 2019 to November 2019. Well pulverized soil was collected from the field of research station and each plastic pot $35 \mathrm{~cm} \times 25 \mathrm{~cm} \times 15 \mathrm{~cm}$ in size was filled with $6 \mathrm{~kg}$ of soil. After leveling the soil surface in each pot, moisture was applied up to field capacity. In each pot, 40 seeds were equally sown on the soil surface in both experiments. Both experiments were laid out in a completely randomized design with four replications. For lab screening, all the trays were placed in the growth chamber with a constant temperature of $25^{\circ} \mathrm{C}$ and a light period of $12 \mathrm{~h}$. The relative humidity during the complete execution of lab experiment was maintained at $65 \%$. For greenhouse experiment, all the trays were placed in greenhouse under natural environmental conditions. Moisture was applied to each try when declined.

Stand Establishment: Emergence was recorded on daily basis until a constant was achieved. Final emergence (\%) was taken at the end of experiment (AOSA, 1990). Mean emergence time (days) was recorded as per the equation of ISTA (2015).

Seedling Vigor: Seedling length of five randomly selected from each treatment was measured with the help of measuring tape and 
averaged to get mean length. Similarly, fresh and dry weight of these plants was measured on a weighing balance. For dry weight, plants were dried at $70^{\circ} \mathrm{C}$ till constant weight in an oven (Zafar et al., 2015).

Physiological Parameters: Measurements of $\mathrm{CO}_{2}$ index $\left(\mu \mathrm{mol} \mathrm{mol}{ }^{-1}\right)$, net photosynthetic rate $\left(\mu \mathrm{mol} \mathrm{CO} \mathrm{CO}_{2} \mathrm{~m}^{-2} \mathrm{~s}^{-1}\right)$ and evaporation rate $\left(\mu \mathrm{mol} \mathrm{H}_{2} \mathrm{O} \mathrm{m}^{-2} \mathrm{~s}^{-1}\right.$ ) were made on a fully expanded leaf from top by using an open system LCA-4 ADC (USA) portable infrared gas analyzer.

Biochemical Attributes: To determine the activities of alcohol dehydrogenase and pyruvate decarboxylase, seedling samples were ground and detected by an alcohol dehydrogenase assay kit and a pyruvate decarboxylase test kit.

Statistical Analysis: The data from growth chamber and greenhouse experiments are presented as the mean value \pm standard error of four replicates. By using Statistix 9.0, analysis of variance for all the treatments was performed. Graphical presentation of data was performed by using SigmaPlot 14.0.

\section{Results}

\section{Lab Screening}

Stand Establishment: Seed priming treatments maximally improved the final emergence $(\%)$ of both rice cultivars under well-controlled conditions. Highest values for final emergence (\%) were recorded in experimental units (Cultivar 1 (V1) $=96 \%$, Cultivar $2(\mathrm{~V} 2)=98 \%)$ receiving rice seed primed with $0.75 \% \mathrm{KNO}_{3}$ as compared to control. Seed priming with $1 \% \mathrm{KNO}_{3}$ was also proved to be beneficial in both cultivars (V1=89\%, V2=90\%) for improving final emergence (\%). No variance in final emergence was observed among experimental units receiving rice seed primed $0.50 \%$ and $1 \%$ $\mathrm{KNO}_{3}$ in V2 cultivar (Fig. 1a). Similarly, minimum mean emergence time (MET) was recorded in rice seeds primed with $0.75 \%$ followed by $1 \% \mathrm{KNO}_{3}$. Highest values for MET was recorded in control in both cultivars (Fig. 1b). Collectively, statistical analysis of data revealed that seed primed with $\mathrm{KNO}_{3}$ proved better in improving stand establishment of both rice cultivars as compared to control.

Seedling Vigor: Seedling length of both rice cultivars is graphically presented in Fig. $2 \mathrm{a}$ and data revealed that maximum seedling vigor in both cultivars was achieved in rice seeds primed with $0.75 \%(\mathrm{~V} 1=8.10 \mathrm{~cm}, \mathrm{~V} 2=8.24 \mathrm{~cm})$ followed by $1 \%(\mathrm{~V} 1=7.88 \mathrm{~cm}, \mathrm{~V} 2=7.91 \mathrm{~cm})$ and $0.50 \%(\mathrm{~V} 1=7.43 \mathrm{~cm}, \mathrm{~V} 2=7.69 \mathrm{~cm}) \mathrm{KNO}_{3}$ solutions as compared to control $(\mathrm{V} 1=6.83 \mathrm{~cm}$, $\mathrm{V} 2=6.71 \mathrm{~cm}$ ) (Fig. 2a). Seed priming with $\mathrm{KNO}_{3}$ also proved effective in improving the seedling fresh and dry weight, nonetheless effect of different cultivars was not pronounced. Plants in both cultivars raised from seeds treated with $0.75 \% \mathrm{KNO}_{3}$ depicted highest values for seedling fresh (V1=34.45mg, V2=37.67mg) (Fig. 2b) and dry weight $(\mathrm{V} 1=18.12 \mathrm{mg}, \mathrm{V} 2=19.01 \mathrm{mg})$ as compared to other treatments and control (Fig. 2c). No apparent difference in seedling fresh and dry weight was observed among rice seed treated with $0.50 \%$ and $1.0 \% \mathrm{KNO}_{3}$ in both cultivars.

\section{Greenhouse Screening}

Stand Establishment: A variable trend of primed and non-primed final emergence (\%) was observed in both cultivars under greenhouse screening. Rice seed in both cultivars treated with $0.75 \% \mathrm{KNO}_{3}$ steadily depicted highest values for final emergence (V1=95\%, V2 $=98 \%$ ), while an opposite drift was examined in control (V1=77\%, V2=80\%). Rice seeds treated with $1 \% \mathrm{KNO}_{3}$ also proved to be successful in both cultivars ( V1=88\%, $\mathrm{V} 2=91 \%$ ) for improving final emergence $(\%)$ under greenhouse conditions. No variance in final emergence was observed among experimental units receiving rice seed primed $0.50 \%$ and $1 \% \mathrm{KNO}_{3}$ in both cultivars (Fig. 3a). However, minimum mean emergence time (MET) was recorded in rice seeds primed with $0.75 \%$ followed by $1 \% \mathrm{KNO}_{3}$ in both cultivars compared to other treatments and control. In addition, both cultivars showed highest values for MET in experimental units receiving control (Fig. 3b). 

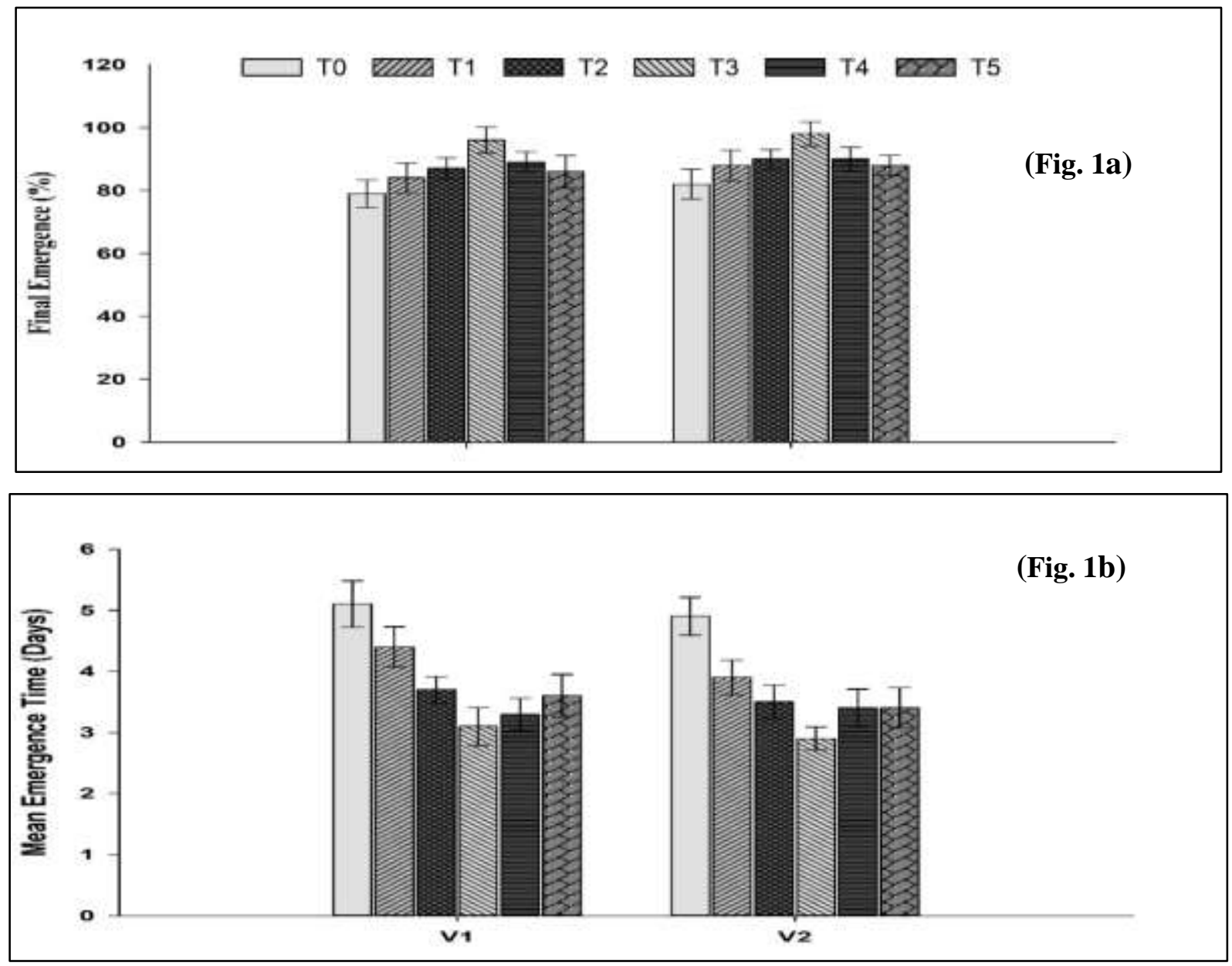

Figure 1a and b. Effect of seed priming with $\mathrm{KNO}_{3}$ on stand establishment of two cultivars of rice in growth chamber.

V1=Basmati-515, V2=Basmati=385: T0=Control, $T 1=0.25 \% \quad \mathrm{KNO}_{3}, \quad \mathrm{~T} 2=0.50 \% \quad \mathrm{KNO}_{3}$, $\mathrm{T} 3=0.75 \% \mathrm{KNO}_{3}, \mathrm{~T} 4=1.0 \% \mathrm{KNO}_{3}, \mathrm{~T} 5=1.25 \% \mathrm{KNO}_{3}$.

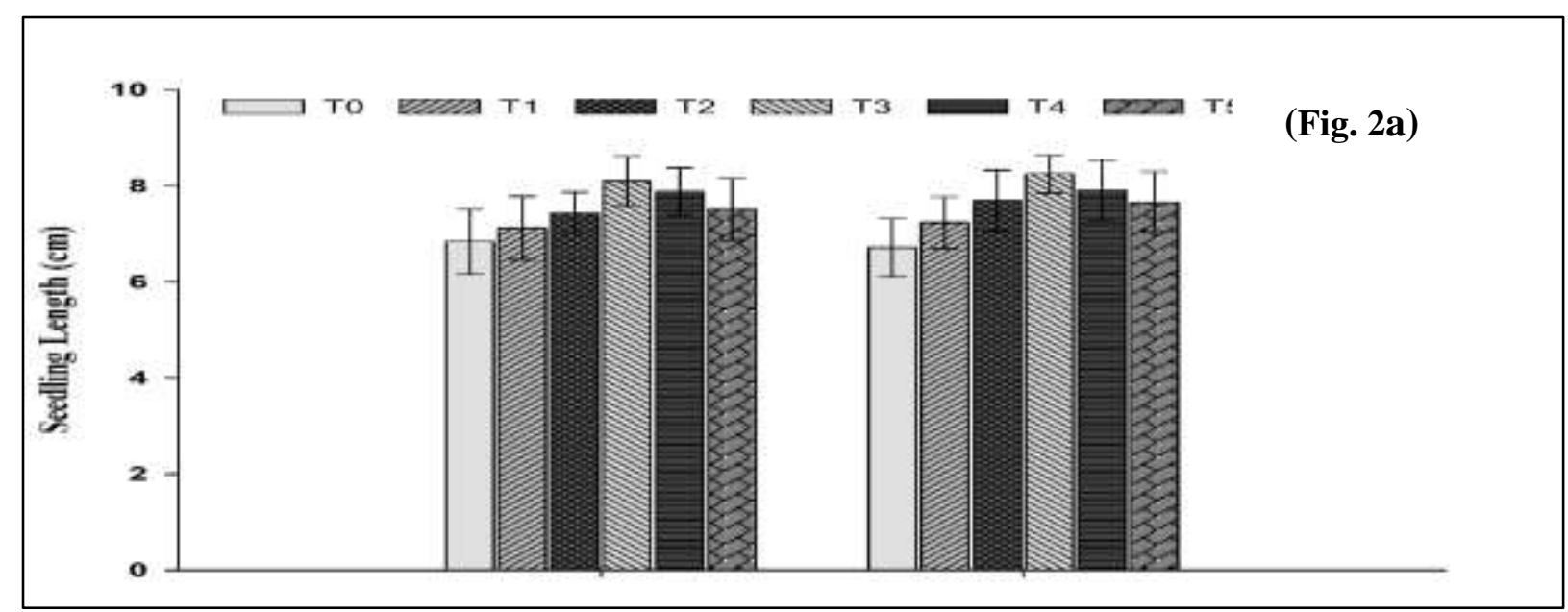



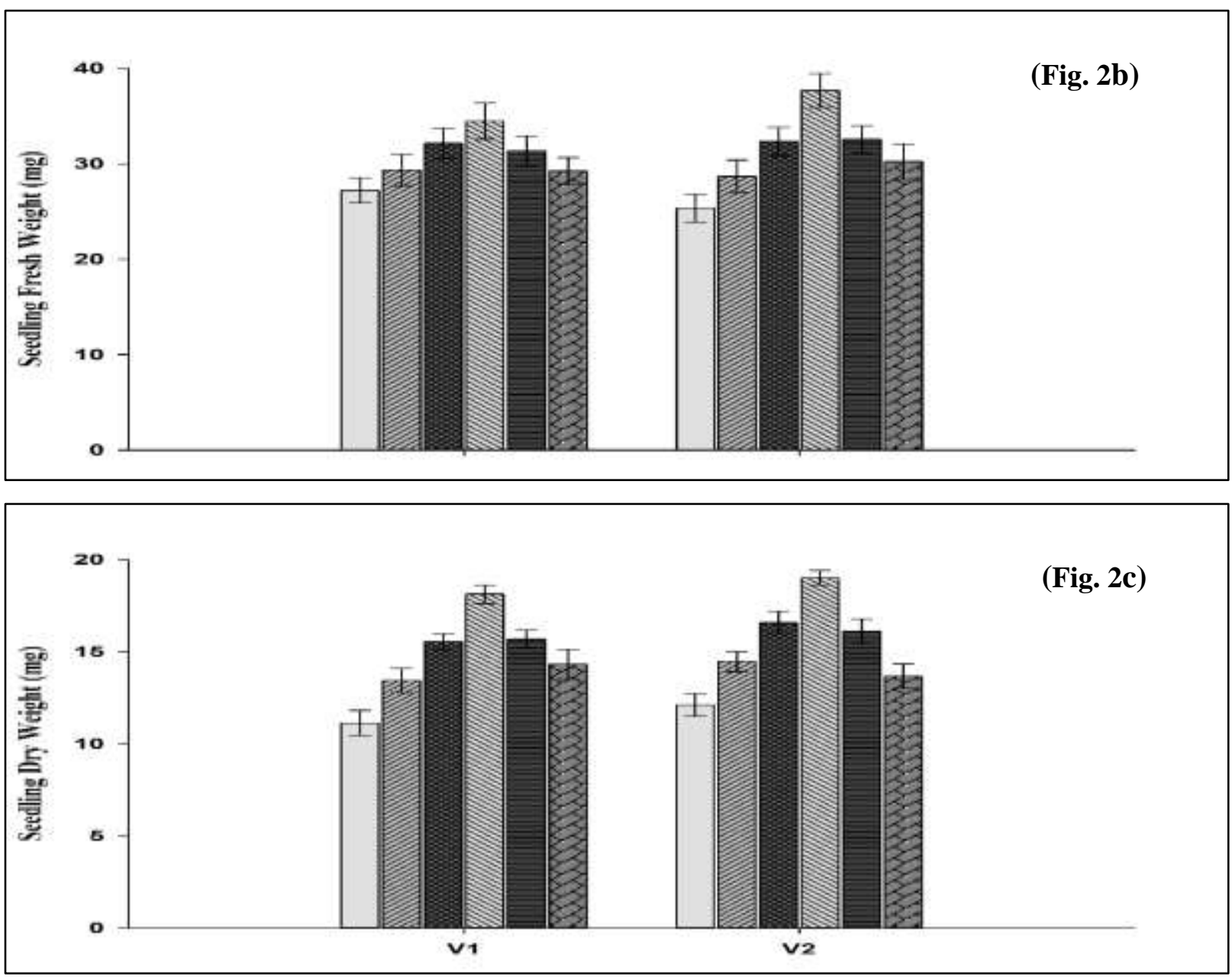

Figure 2a,b and c. Seedling vigor attributes of two cultivars of rice under the influence of seed priming with $\mathrm{KNO}_{3}$ in growth chamber.

V1=Basmati-515, V2=Basmati=385: $\quad \mathrm{T} 0=$ Control, $\quad \mathrm{T} 1=0.25 \% \quad \mathrm{KNO}_{3}, \quad \mathrm{~T} 2=0.50 \% \quad \mathrm{KNO}_{3}$, $\mathrm{T} 3=0.75 \% \mathrm{KNO}_{3}, \mathrm{~T} 4=1.0 \% \mathrm{KNO}_{3}, \mathrm{~T}_{5}=1.25 \% \mathrm{KNO}_{3}$.

Seedling Vigor: Statistical analysis of data pertaining to seedling vigor depicted that the effect of seed priming treatments was significant in both cultivars. However, both cultivars did not exhibit pronounced effect on seedling vigor. All priming treatments significantly improved the seedling length in both cultivars, whereas maximum seedling was achieved in rice seed primed with $0.75 \%$ $(\mathrm{V} 1=7.90 \mathrm{~cm}, \mathrm{~V} 2=8.09 \mathrm{~cm})$ followed by $1 \%$ $(\mathrm{V} 1=7.65 \mathrm{~cm}, \mathrm{~V} 2=7.74 \mathrm{~cm}) \mathrm{KNO}_{3}$ solutions. Furthermore, lowest vales for seedling length in both cultivars was observed in control $(\mathrm{V} 1=6.41 \mathrm{~cm}, \mathrm{~V} 2=6.51 \mathrm{~cm})$ (Fig. 3a). Plants in both cultivars raised from seeds treated with $0.75 \% \mathrm{KNO}_{3}$ depicted highest values for seedling fresh $(\mathrm{V} 1=33.45 \mathrm{mg}, \mathrm{V} 2=36.54 \mathrm{mg})$
(Fig. 3b) and dry weight (V1=16.78mg, $\mathrm{V} 2=19.99 \mathrm{mg}$ ) as compared to other treatments and control (Fig. 3c). Overall, statistical analysis of data revealed that seed priming with $0.75 \% \quad \mathrm{KNO}_{3}$ proved successful in improving seedling vigor of both rice cultivars as compared to other treatments and control.

Physiological and Biochemical Attributes: Analysis of variance of data showed that seed priming treatments significantly improved the physiological and biochemical attributes of both cultivars, while effect of cultivars was not significant. Highest photosynthesis rate, evaporation rate and $\mathrm{CO}_{2}$ were observed in rice seeds treated with $0.75 \% \mathrm{KNO}_{3}$, whereas lowest values were examined in non-treated control. Statistical analysis of data demonstrated that $\mathrm{PDH}$ and $\mathrm{ADH}$ activities 
were significantly influenced by seed priming treatments. Though all the seed priming treatments proved successful for improving the biochemical attributes however lowest values were observed in experimental units receiving rice seed treated with $0.75 \% \mathrm{KNO}_{3}$ under greenhouse screening. Highest values for PDH and ADH activities were observed in control (Table 1).
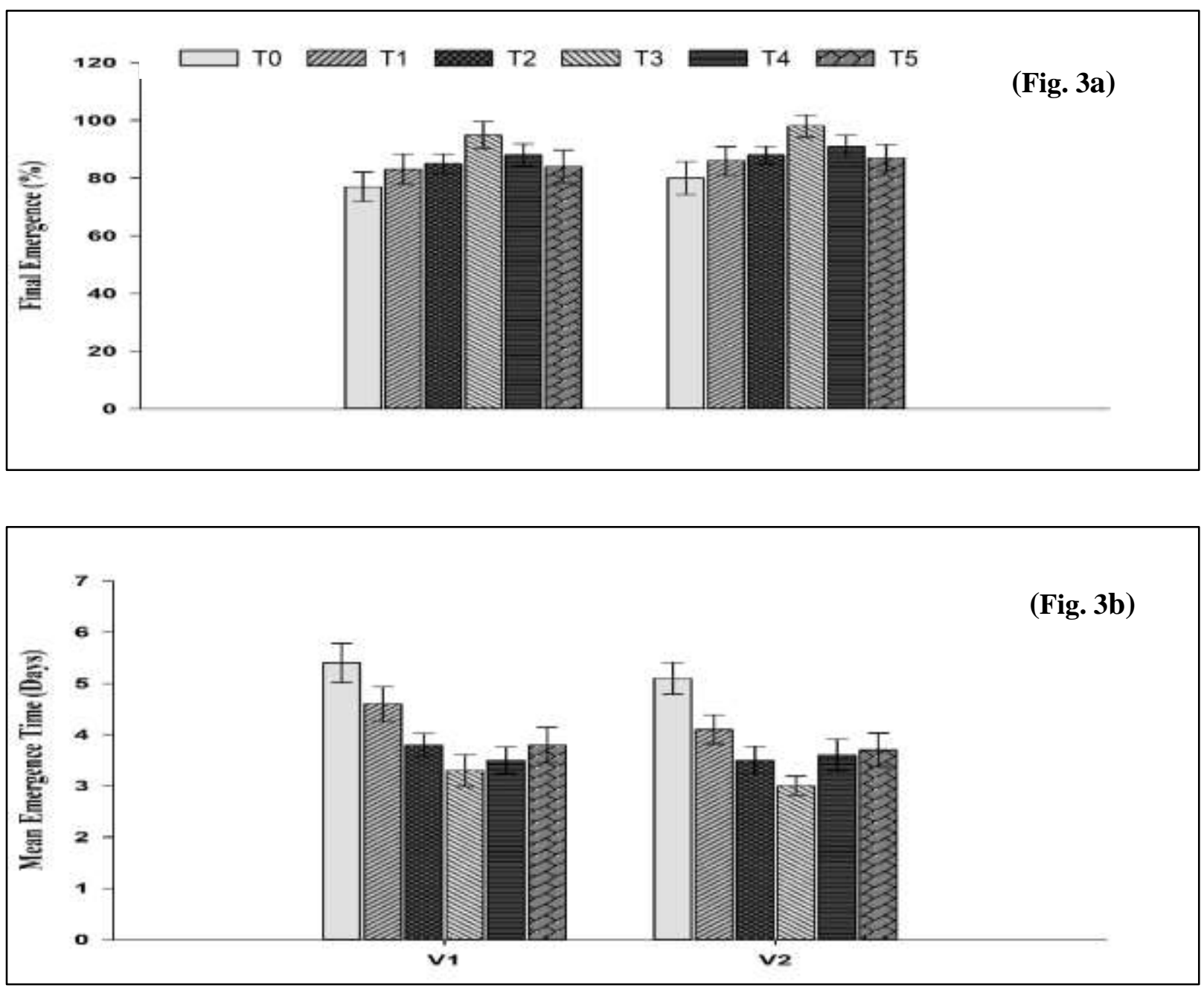

Figure 3. Effect of seed priming with $\mathrm{KNO}_{3}$ on stand establishment of two rice cultivars in greenhouse.

V1=Basmati-515, V2=Basmati $=385: T 0=$ Control, $\mathrm{T} 1=0.25 \% \quad \mathrm{KNO}_{3}, \mathrm{~T} 2=0.50 \% \quad \mathrm{KNO}_{3}, \mathrm{~T} 3=0.75 \%$ $\mathrm{KNO}_{3}, \mathrm{~T} 4=1.0 \% \mathrm{KNO}_{3}, \mathrm{~T} 5=1.25 \% \mathrm{KNO}_{3}$.

Seedling Vigor: Statistical analysis of data pertaining to seedling vigor depicted that the effect of seed priming treatments was significant in both cultivars. However, both cultivars did not exhibit pronounced effect on seedling vigor. All priming treatments significantly improved the seedling length in both cultivars, whereas maximum seedling was achieved in rice seed primed with $0.75 \%$ $(\mathrm{V} 1=7.90 \mathrm{~cm}, \mathrm{~V} 2=8.09 \mathrm{~cm})$ followed by $1 \%$ $(\mathrm{V} 1=7.65 \mathrm{~cm}, \mathrm{~V} 2=7.74 \mathrm{~cm}) \mathrm{KNO}_{3}$ solutions. Furthermore, lowest vales for seedling length in both cultivars was observed in control $(\mathrm{V} 1=6.41 \mathrm{~cm}, \mathrm{~V} 2=6.51 \mathrm{~cm})$ (Fig. 4a). Plants in both cultivars raised from seeds treated with $0.75 \% \mathrm{KNO}_{3}$ depicted highest values for seedling fresh $(\mathrm{V} 1=33.45 \mathrm{mg}, \mathrm{V} 2=36.54 \mathrm{mg})$ (Fig. 4b) and dry weight (V1=16.78mg, $\mathrm{V} 2=19.99 \mathrm{mg}$ ) as compared to other treatments and control (Fig. 4c). Overall, statistical analysis of data revealed that seed priming with $0.75 \% \quad \mathrm{KNO}_{3}$ proved successful in improving seedling vigor of both rice cultivars as compared to other treatments and control. 

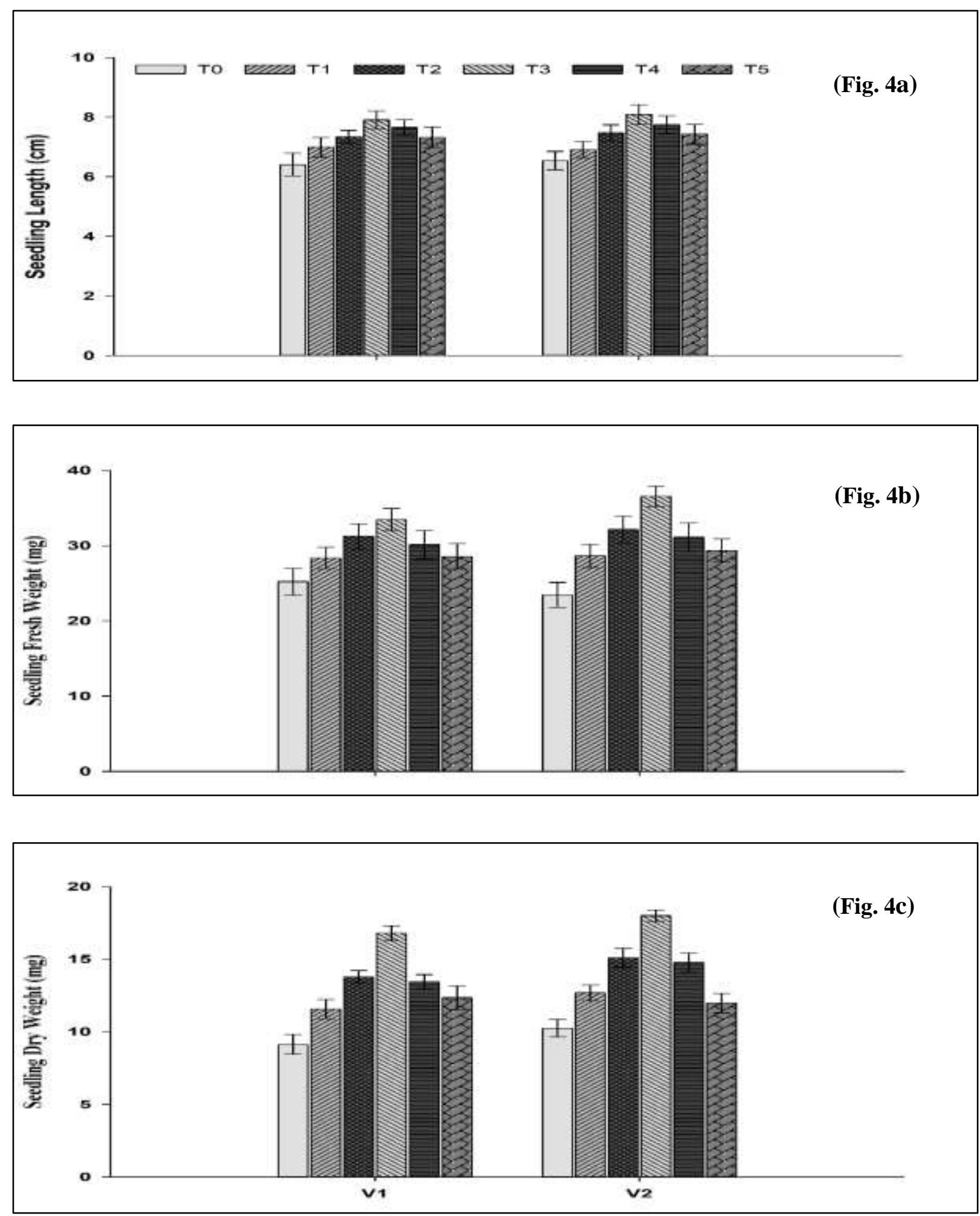

Figure 4. Seedling vigor attributes of two cultivars of rice under the influence of seed priming with $\mathrm{KNO}_{3}$ in greenhouse.

$\mathrm{V} 1=$ Basmati-515, V2=Basmati=385: $\mathrm{T} 0=\mathrm{Control}, \mathrm{T} 1=0.25 \% \quad \mathrm{KNO}_{3}, \mathrm{~T} 2=0.50 \% \quad \mathrm{KNO}_{3}, \mathrm{~T} 3=0.75 \%$ $\mathrm{KNO}_{3}, \mathrm{~T} 4=1.0 \% \mathrm{KNO}_{3}, \mathrm{~T} 5=1.25 \% \mathrm{KNO}_{3}$. 
Table 1. Variations in physiological and biochemical attributes of two rice cultivars under the influence of seed priming with $\mathrm{KNO}_{3}$ in lab.

\begin{tabular}{|c|c|c|c|c|c|c|}
\hline \multirow{2}{*}{ Cultivars } & \multirow{2}{*}{ Treatments } & \multicolumn{3}{|c|}{ Physiological attributes } & \multicolumn{2}{|c|}{ Biochemical attributes } \\
\hline & & $\begin{array}{l}\text { Photosynthesis rate } \\
\left(\mu \mathrm{mol} \mathrm{CO}_{2} \mathrm{~m}^{-2} \mathrm{~s}^{-1}\right)\end{array}$ & $\begin{array}{l}\text { Evaporation rate } \\
\left(\mu \mathrm{mol} \mathrm{H}_{2} \mathrm{O} \mathrm{m}^{-2} \mathbf{s}^{-1}\right)\end{array}$ & 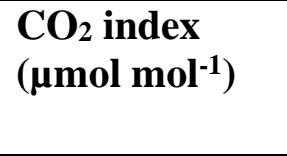 & $\begin{array}{l}\text { Alcohol } \\
\text { dehydrogenase } \\
\left(\mathbf{U g}^{-1} \text { FW) }\right.\end{array}$ & $\begin{array}{l}\text { Pyruvate } \\
\text { decarboxylase } \\
\left(\mathbf{U g}^{-1} \mathbf{F W}\right)\end{array}$ \\
\hline \multirow{6}{*}{ Basmati-515 } & T0 & $10.67 \pm 0.05 \mathrm{c}$ & $0.91 \pm 0.09 \mathrm{c}$ & $120.33 \pm 5.5 \mathrm{~d}$ & $1.72 \pm 0.09 \mathrm{a}$ & $1.62 \pm 0.09 \mathrm{a}$ \\
\hline & T1 & $12.67 \pm 0.08 \mathrm{bc}$ & $1.09 \pm 0.09 \mathrm{bc}$ & $131.33 \pm 6.2 \mathrm{~cd}$ & $1.44 \pm 0.07 \mathrm{ab}$ & $1.33 \pm 0.05 \mathrm{ab}$ \\
\hline & T2 & $14.83 \pm 0.06 \mathrm{abc}$ & $1.31 \pm 0.08 \mathrm{~b}$ & $148.33 \pm 5.2 \mathrm{bc}$ & $1.29 \pm 0.06 \mathrm{bc}$ & $1.17 \pm 0.08 \mathrm{bc}$ \\
\hline & T3 & $17.67 \pm 0.04 \mathrm{a}$ & $1.72 \pm 0.06 \mathrm{a}$ & $172.00 \pm 5.3 \mathrm{a}$ & $1.11 \pm 0.08 \mathrm{c}$ & $1.02 \pm 0.04 \mathrm{c}$ \\
\hline & T4 & $15.83 \pm 0.06 \mathrm{ab}$ & $1.40 \pm 0.06 \mathrm{ab}$ & $154.33 \pm 4.8 \mathrm{ab}$ & $1.33 \pm 0.06 \mathrm{bc}$ & $1.24 \pm 0.07 \mathrm{bc}$ \\
\hline & T5 & $14.00 \pm 0.07 \mathrm{abc}$ & $1.33 \pm 0.08 \mathrm{~b}$ & $142.67 \pm 4.8 \mathrm{bc}$ & $1.54 \pm 0.09 \mathrm{ab}$ & $1.43 \pm 0.06 \mathrm{ab}$ \\
\hline & LSD at $p \leq 0.05$ & 1.23 & 0.31 & 18.71 & 0.31 & 0.29 \\
\hline \multirow{6}{*}{ Basmati-385 } & T0 & $9.69 \pm 0.05 \mathrm{c}$ & $1.02 \pm 0.08 \mathrm{c}$ & $122.33 \pm 5.12 \mathrm{c}$ & $1.82 \pm 0.08 \mathrm{a}$ & $1.73 \pm 0.08 \mathrm{a}$ \\
\hline & T1 & $11.63 \pm 0.08 \mathrm{bc}$ & $1.19 \pm 0.06 \mathrm{bc}$ & $132.67 \pm 5.98 \mathrm{bc}$ & $1.51 \pm 0.09 \mathrm{abc}$ & $1.42 \pm 0.09 \mathrm{abc}$ \\
\hline & $\mathbf{T} 2$ & $13.89 \pm 0.06 \mathrm{abc}$ & $1.39 \pm 0.09 \mathrm{~b}$ & $152.33 \pm 4.82 \mathrm{ab}$ & $1.40 \pm 0.08 \mathrm{bc}$ & $1.29 \pm 0.08 \mathrm{bc}$ \\
\hline & T3 & $16.64 \pm 0.04 \mathrm{a}$ & $1.81 \pm 0.05 \mathrm{a}$ & $174.00 \pm 5.83 \mathrm{a}$ & $1.22 \pm 0.05 \mathrm{c}$ & $1.10 \pm 0.05 \mathrm{c}$ \\
\hline & T4 & $14.88 \pm 0.06 \mathrm{ab}$ & $1.51 \pm 0.07 \mathrm{ab}$ & $155.33 \pm 4.89 \mathrm{ab}$ & $1.43 \pm 0.06 \mathrm{bc}$ & $1.31 \pm 0.06 \mathrm{bc}$ \\
\hline & T5 & $13.01 \pm 0.07 \mathrm{abc}$ & $1.40 \pm 0.05 \mathrm{~b}$ & $144.00 \pm 5.01 \mathrm{bc}$ & $1.65 \pm 0.07 \mathrm{ab}$ & $1.56 \pm 0.07 \mathrm{ab}$ \\
\hline & LSD at $p \leq 0.05$ & 1.03 & 0.34 & 28.00 & 0.32 & 0.31 \\
\hline
\end{tabular}




\section{Discussion}

Osmopriming of seed by $\mathrm{KNO}_{3}$ affected the seed emergence and the speed of seed germination. Osmopriming induces the reduction in intake of water in phase-I of germination, causing prolonged duration of phase-2, resulting commencement of major event before the emergence of radicle (Nonogaki and Nonogaki, 2016). This major event includes metabolic changes such as repair of DNA and increase in biosynthesis of RNA (Bray, 2017), and enhancement in the respiration process of seed (Singh et al., 2013). It indicates that the time of seed imbibition is very important for osmopriming. For the study of osmopriming of rice (Oryza sativa L.) seed with different levels of $\mathrm{KNO}_{3}$, therefore it is important to know about the emergence percentage and mean emergence time (MET). The results of present study indicate that the performance of osmopriming of both cultivars of rice with $0.75 \% \mathrm{KNO}_{3}$ was appreciable in lab screening as well as greenhouse (Fig. 1 and $3)$. The pattern of seedling emergence (\%) and MET was almost same in both cultivars as well as both sites (lab and greenhouse). The time of water intake by the seed during priming can very within the cultivars which can affect the performance of osmoticum $\left(\mathrm{KNO}_{3}\right)$ (Kiers et al., 2008), but in our study the difference between the performance of both cultivars was non-significant. Emergence of the seed is the stage where it is determined that either the seedling will further grow or not. The emergence percentage is calculated from the number of emerged seedlings from number of primed seeds sown (International Seed Testing Association, 2015). The data shown in figure 1 and 3 depicts that the osmopriming of rice seed with $0.75 \% \mathrm{KNO}_{3}$ is better than all other treatments in term of emergence percentage and MET. Our study is in correspondence with another study who revealed that emergence percentage of wheat seed was decreased with the increase in $\mathrm{KNO}_{3}$ concentration (Shafiei Abnavi and Ghobadi, 2012). This indicates that the $\mathrm{KNO}_{3}$ concentration above than a certain level may not be appropriate for cereals. Osmopriming with $1 \% \mathrm{KNO}_{3}$ was found useful in term of emergence percentage in sorghum (Shehzad et al., 2012). Besides, soybean seed priming with $1 \% \mathrm{KNO}_{3}$ for 1 day enhanced the emergence percentage as compared to untreated seeds, both in lab and field experiments (Mohammadi, 2009). Seedling vigor is the combine result of the emerged seeds in a wide range of biotic and abiotic factors (International Seed Testing Association, 2015). Seedling vigor is not a single measurable entity, but it is a sum of many growth parameters such as seedling length, seedling fresh weight and seedling dry weight (International Seed Testing Association, 2015). Maximum vigor was observed when seed priming with $0.75 \%$ $\mathrm{KNO}_{3}$ was done (Fig. 2 and 4). Our study is in line with another study in which seedling vigor of wheat was improved by the priming with $\mathrm{KNO}_{3}$ (Shafiei Abnavi and Ghobadi, 2012). Similar results were found in corn when the osmopriming of seed was done with $1 \% \mathrm{KNO}_{3}$ (Hadinezhad et al., 2013). Our findings are similar with other studies, in which the shoot length of tomato and watermelon was increased by the osmopriming with $\mathrm{KNO}_{3}$ (Demir and Van De Venter, 1999; Mirabi \& Hasanabadi, 2012). Seed priming with $\mathrm{KNO}_{3}$ can cause significant increase in seedling vigor of wheat crop as compared to hydro-priming or dry broadcasting (Basra et al., 2003). The growth and development of plant is based upon a process; photosynthesis. While its performance is mostly dependent on the opening/closing of stomata, causing decrease in photosynthetic rate, respiration rate and $\mathrm{CO}_{2}$ index (Shu et al., 2016). The results of present study revealed that the maximum photosynthesis rate, evaporation rate and $\mathrm{CO}_{2}$ index was observed in the rice seeds which were primed with $0.75 \% \mathrm{KNO}_{3}$ (Table 1). Whereas the seedlings of control treatments showed inferior results as compared to other osmopriming treatments. Our study is in corroboration with another study in which the increased photosynthetic rate, respiration rate and $\mathrm{CO}_{2}$ index of cucumber seedlings as the result of seed priming with $\mathrm{KNO}_{3}$ was reported (Anwar et al., 2020). Photosynthesis rate of the seedlings has a positive correlation with the 
growth of seedling (Anwar et al., 2020). A previous study indicated that the leaf nitrogen and chlorophyll contents have a positive correlation, and can derive the photosynthesis rate being a key molecule for photosynthesis (De Castro et al., 2014). The results of present study revealed that the biochemical attributes e.g. alcohol dehydrogenase $\left(\mathrm{Ug}^{-1} \mathrm{FW}\right)$ and pyruvate decarboxylase $\left(\mathrm{Ug}^{-1} \mathrm{FW}\right)$ of rice were suppressed by osmopriming of seed with $\mathrm{KNO}_{3}$. Maximum suppression was observed in those seedlings who were treated with $0.75 \% \% \mathrm{KNO}_{3}$, while minimum suppression was seen in non-primed seedlings. A previous study expressed that seed priming with potassium nitrate $\left(\mathrm{KNO}_{3}\right)$ improved the biochemical indices of Chicory (Cichorium intybus L.) (Dehkordi et al., 2012).

\section{Conclusion}

Good quality seed is always in demand by the farmers and seed industry. Therefore, present study was conducted to improve the rice seed quality by seed priming with $\mathrm{KNO}_{3}$. The results depicted that seed priming with $0.75 \% \mathrm{KNO}_{3}$ proved successful in improving stand establishment, vigor and physiological attributes. The improved performance might by linked with better activities of $\mathrm{ADH}$ and $\mathrm{PDH}$. Therefore, present research provides basis for further transcriptomics/metabolomics/proteomics basis of primed seeds with $\mathrm{KNO}_{3}$.

\section{Conflicts of Interest}

None

\section{References}

Ahmadvand, G., Soleimani, F., Saadatian, B., \& Pouya, M. (2012). Effects of seed priming on germination and emergence traits of two soybean cultivars under salinity stress. International Journal of Applied and Basic Sciences, 3(2): 234-241.

Ahmed, N., Zhang, Y., Yu, H., Gabar, A., Zhou, Y., Li, Z., \& Zhang, M. (2019). Seed priming with glycine betaine improve seed germination characteristics and antioxidant capacity of wheat (Triticum aestivum L.) seedlings under water-stress conditions. Applied Ecology and Environmental Research, 17(4): 8333-8350.

Anwar, A., Yu, X., \& Li, Y. (2020). Seed priming as a promising technique to improve growth, chlorophyll, photosynthesis and nutrient contents in cucumber seedlings. Notulae Botanicae Horti Agrobotanici Cluj-Napoca, 48(1), 116-127.

Association of Official Seed Analysis. (1990). Rules for testing seeds. Journal of Seed Technology, 12: 101-112.

Basra, S. M. A., Farooq, M., Tabassam, R., \& Ahmad, N. (2005). Physiological and biochemical aspects of pre-sowing seed treatments in fine rice (Oryza sativa L.). Seed Science and Technology, 33: 623-628.

Basra, S., Pannu, I., \& Afzal, I. (2003). Evaluation of seedling vigor of hydro and matriprimed wheat (Triticum aestivum L.) seeds. International Journal of Agricultural Biology, 5(2): 121-123.

Bewley, J. D., Bradford, K. J., Hilhorst, H. W. M., \& Nonogaki, H. (2013). Seeds: Physiology of development, germination and dormancy, 3rd edition. In Seeds: Physiology of Development, Germination and Dormancy, 3rd Edition. https://doi.org/10.1007/978-1-4614-4693-4.

Bray, C. M. (2017). Biochemical processes during the osmopriming of seeds. In Seed Development and Germination. https://doi.org/10.1201/9780203740071.

Chun, Y., Fang, J., Zafar, S.A., Shang, J., Zhao, J., Yuan, S., \& Li X. (2020). MINI SEED 2 (MIS2) encodes a receptor-like kinase that controls grain size and shape in rice. Rice, 13:7.

Dashtmian, F. (2014). Improving rice seedling physiological and biochemical processes under low temperature by seed priming with salicylic acid. International Journal of Plant, Animal and Environmental Sciences, 4(2): 565-572.

De Castro, F. A., Campostrini, E., Netto, A. T., De Menezes De Assis Gomes, M., Ferraz, T. M., \& Glenn, D. M. (2014). Portable chlorophyll meter (PCM-502) values are related to total chlorophyll concentration and photosynthetic capacity in papaya (Carica papaya L.). Theoretical and Experimental Plant Physiology, 26, 201-210.

Dehkordi, F. S., Nabipour, M., \& Meskarbashee, M. (2012). Effect of priming on germination and biochemical indices of chicory (Cichorium intybus L.) seed. Science Series Data Report, 4(9): 24-33.

Demir, I., \& Van De Venter, H. A. (1999). The effect of priming treatments on the performance of watermelon (Citrullus lanatus (Thunb.) Matsum. and Nakai) seeds under temperature and osmotic stress. Seed Science and Technology, 27: 871-876.

Farooq, M., Basra, S. M. A., \& Khan, M. B. (2007). Seed priming improves growth of nursery seedlings and yield of transplanted rice. Archives of Agronomy and Soil Science, 53(3): 
315-326.

Farooq, M., Basra, S. M. A., Ahmad, N., \& Murtaza, G. (2009). Enhancing the performance of transplanted coarse rice by seed priming. Paddy and Water Environment, 7: 55-63.

Hadinezhad, P., Payamenur, V., Mohamadi, J., \& Ghaderifar, F. (2013). The effect of priming on seed germination and seedling growth in Quercus castaneifolia. Seed Science and Technology, 41(1):121-124.

Harris, D., Joshi, A., Khan, P. A., Gothkar, P., \& Sodhi, P. S. (1999). On-farm seed priming in semi-arid agriculture: Development and evaluation in maize, rice and chickpea in India using participatory methods. Experimental Agriculture, 35: 15-29.

Hussian, I., Ahmad, R., Farooq, M., \& Wahid, A. (2013). Seed priming improves the performance of poor quality wheat seed. International Journal of Agriculture and Biology, 15(6): 1560-8530.

International Seed Testing Association. (2015). ISTA Rules Full Issue. International Rules for Seed Testing, $1-276$. https://doi.org/10.15258/istarules.2015.F.

Kiers, E. T., Leakey, R. R. B., Izac, A.-M., Heinemann, J. A., Rosenthal, E., Nathan, D., \& Jiggins, J. (2008). Ecology: Agriculture at a crossroads. Science, 320: 320-321.

McKersie, B. D. (2002). Principles of seed science and technology. Plant Science, 162, 849.

Mirabi, E., \& Hasanabadi, M. (2012). Effect of seed priming on some characteristic of seedling and seed vigor of tomato (Lycopersicun esculentum). Journal of Advanced Laboratory Research in Biology, 3(3): 237-240.

Mohammadi, G. (2009). The effect of seed priming on plant traits of late-spring seeded soybean (Glycine max L.). American-Eurasian Journal of Agriculture and Environmental Science, 5(3): 322-326.

Nonogaki, M., \& Nonogaki, H. (2016). Germination. In: Encyclopedia of Applied Plant Sciences (pp. 509-512). https://doi.org/10.1016/B978-012-394807-6.00201-X.

Razaji, A., Asli, D. E., \& Farzanian, M. (2012). The effects of seed priming with ascorbic acid on drought tolerance and some morphological and physiological characteristics of safflower (Carthamus tinctorius L.). Annals of Biological Research, 3(8): 3984-3989.

Ruan, S., Xue, Q., \& Tylkowska, K. (2002). The influence of priming on germination of rice (Oryza sativa L.) seeds and seedling emergence and performance in flooded soil. Seed Science and Technology, 30(1): 61-67.

Shafiei Abnavi, M., \& Ghobadi, M. (2012). The effects of source of oriming and post-priming storage duration on seed germination and seedling growth characteristics in wheat (Triticum aestivem L.). Journal of Agricultural Science, 4(9).256

Shehzad, M., Ayub, M., Ahmad, A. U. H., \& Yaseen, M. (2012). Influence of priming techniques on emergence and seedling growth of forage sorghum (sorghum bicolor L.). Journal of Animal and Plant Sciences, 22(1): 154-158.

Shu, S., Tang, Y., Yuan, Y., Sun, J., Zhong, M., \& Guo, S. (2016). The role of 24-epibrassinolide in the regulation of photosynthetic characteristics and nitrogen metabolism of tomato seedlings under a combined low temperature and weak light stress. Plant Physiology and Biochemistry, 107: 344-353.

Singh, G., Gill, S. S., \& Sandhu, K. K. (2013). Improved performance of muskmelon (Cucumis melo) seeds with osmo conditioning. Acta Agrobotanica, 52: 121-137.

Xu, P., Xiang, Y., Zhu, H., Xu, H., Zhang, Z., Zhang, C., Zhang, L., \& Ma, Z. (2009). Wheat cryptochromes: subcellular localization and involvement in photo-morphogenesis and osmotic stress responses. Plant Physiology, 149(2): 760-774.

Zafar, S.A., Hameed, A., Khan, A.S., Ashraf, M., Qamar, Z., Li, X., \& Siddique K.H.M. (2020). Agronomic, physiological and molecular characterization of rice mutants revealed key role of ROS and catalase in high temperature stress tolerance. Functional Plant Biology, 47(5): 440-453.

Zafar, S.A., Hameed, A., Nawaz, M.A., Wei, M., Noor, M.A., Hussain, M., \& Rehman, M. (2018). Mechanisms and molecular approaches for heat tolerance in rice (Oryza sativa L.) under climate change scenario. Journal of Integrative Agriculture, 17(4): 726-738.

Zafar, S.A., Shokat, S., Ahmed, H.G.M., Khan, A., Ali, M.Z., \& Atif, R.M. (2015). Assessment of salinity tolerance in rice using seedling based morpho-physiological indices. Advancements in Life Sciences, 2(4): 142-149. 